\title{
Handling of Morpho-syntactic Learners Errors in Tanzanian English Language Classrooms
}

\author{
Rafiki Yohana Sebonde \\ Department of Foreign Languages and Literature, University of Dodoma, P.O.BOX 626, Tanzania \\ John Misana Biseko \\ Department of Foreign Languages and Literature, University of Dodoma, P.O.BOX 626, Tanzania
}

\begin{abstract}
This paper examines issues related to morpho-syntactic errors among secondary school students in Tanzanian English Language Classrooms (ELCs). Specifically, the study assesses the corrective feedback techniques that teachers use to handle their students' morpho-syntactic errors (both written and spoken errors). The data reveal that a total of four Corrective Feedback techniques are commonly used in Tanzanian ELCs. These techniques include focused Corrective Feedback, direct Corrective Feedback, indirect Corrective Feedback and metalinguistic Corrective Feedback. On top of that, it was discovered that teachers prefer the use of indirect Corrective Feedback when they mark written assignments while explicit and recast are the most applied techniques in handling students' oral errors.
\end{abstract}

Index Terms-English language, learner's errors, corrective feedback

\section{INTRODUCTION}

Second language (hereafter L2) /foreign language (hereafter FL) learners' errors and their subsequent corrective feedback (hereafter CF) are among the major topics in the field of second language learning research. In general, researchers have been making efforts to discover how L2/FL learners' errors can be used by teachers to enhance their teaching. Some of the areas that have attracted the attention of researchers are; analysis of L2 students' errors (Darus and Subramaniam, 2009; Nzama, 2010), The role of correction on L2 learning (Semke, 1984; Fathman and Whalley, 1990; Kepner, 1991; Sheppard, 1992; Ferris, 1997; Polio et al., 1998; Ashwell, 2000; Chandler, 2003; Hyland, 2003) and comparison of CF techniques in terms of effectiveness (Lyster and Ranta, 1997; Sheen, 2007; Samar and Shayestefar, 2009; Rakimi and Dastjerdi, 2012).

Findings from these studies have sparked a debate on whether learners' errors and their subsequent corrections have any significance to L2/FL acquisition. Researchers like Semke (1984), Kepner (1991), Sheppard (1992) and Polio et al. (1998) reported against the idea that error correction facilitates L2/FL acquisition. However, more recent studies have shown the effectiveness of error correction. A number of researchers have used control groups and justify that error correction assists in the learning of L2/FL. Examples of such studies include Ashwell (2000), Ferris and Roberts (2001), Chandler (2003), Hyland (2003), Sheen (2007), and Murakami \& Takashima (2008).

The findings that error correction has the role to play in L2/FL learning has changed the direction of studies such that, to many researchers, the issue is no longer whether CF should be done or not, but rather "how should it be done" (Herrera, 2011, p.11). To answer such a question, many studies to date are designed to assess the effectiveness of various $\mathrm{CF}$ techniques so as to identify which type of CF techniques is effective in treating various kinds of errors (Liu, 2008).

In Tanzania, English is taught as a subject in primary schools and a medium of instruction in secondary schools (hereafter SS). Like any other L2/FL learners, Tanzanian students commit errors in the course of learning English. Scholars in this field acknowledge that committing of errors among L2/FL learners is a natural phenomenon which indicates the developmental stage reached by a learner, and they (errors) require appropriate remedies to make the learner successful in his learning. From this ground, Corder (1967) argues that SL/FL learners' errors should be carefully analysed since they have some clues to the understanding of L2 learning process.

In spite of this truth, Ismail (2007) cited in Rubagumya (2010) reports on the painful experience that learners get when they commit errors in Tanzanian English language classrooms (hereafter ELCs). In her work, Ismail reports on the physical punishment that students receive from their teachers when they commit some errors in their assignments. Ismail's report has stimulated a desire to conduct this research in order to reveal the way such errors (particularly morpho-syntactic errors) are treated by English language teachers in secondary school level.

\section{Types of L2/FL learners' errors}

Categorising errors has not been an easy task. Scholars who have dared to classify L2/FL learners' errors differ in types of errors they provide. Thus it is a common phenomenon to find one scholar providing types of errors which are quite different from those provided by another. However, the existence of such disparities has its root in the criteria which are used to classify the errors. Scholars use different basis to classify L2/FL learners' errors, consequently types 
of errors differ from one scholar to another. However this study is using the idea of Brown (1994) and Keshavarz (1999) quoted in Nayernia (2011) who categorise errors basing on language levels. On one hand, Brown (1994) groups errors into phonological errors, lexicon errors, grammatical errors, and discourse errors while on the other hand Keshavarz (1999) divides them into orthographic errors, phonological errors, lexicosemantic errors, and syntactico-morphological errors which is the concern of this study.

In his study on nature and factors for morpho-syntactic L2/FL learners' errors in Tanzanian secondary schools, Biseko (2012) identified seven types depending on their morpho-syntactic nature. The most common four types are, errors related to wrong use of verbs, subordination and coordination errors, pronoun errors and preposition errors while plural formation errors, errors in the use determiners, and double subject marking errors are the three less common errors among them.

Biseko (2012) also identified the possible factors for students' morpho-syntactic Errors in Tanzanian ELCs to be students' mother tongue, interference of Kiswahili, dialects, students are slow learners, lack of confidence, inadequate teachers for the subject, lack of teaching materials, difficulty of the language, incompetent teachers and government policies concerning English language programmes. However, the researcher identified seven factors which are considered to be the most causative of morpho-syntactic errors in ELCs. These factors include; interference of Kiswahili, inherent difficulties of English language (intra English transfer), inadequate exposure to the language use, incompetent models, poor implementation of the syllabus, neglecting of students' affective domain and disvaluing and maltreatment of learners' errors. Having known the nature and possible factors for morpho-syntactic L2/FL Learners' Errors in Tanzanian ELCs, this study presents the way those errors are handled.

\section{Area of the Study and Methods of Data Collection}

The study was carried out in Dodoma region from November 2011 to March 2012. Dodoma is a centrally positioned administrative region in Tanzania and it lies between $40^{\circ} \mathrm{S}-70^{\circ} \mathrm{S}$ and $350^{\circ} \mathrm{E}-370^{\circ} \mathrm{E}$. The selection of Dodoma region as a site for this study based on one major factor and that is the social economic level of the region. According to the Economic Commission for Africa (2003) the region is grouped in the category of regions with average poverty in relation to other regions in the country. This implies that the social economic level of the region is average as well. Since the economy of the place affects the provision of education, no doubt that this region with average economy is a good case study whose results can be generalised and provide a real picture for the whole country.

Nine schools were randomly selected from three districts which are Dodoma municipal, Mpwapwa and Bahi. A form three class was purposely selected to represent all forms in (o-level) secondary schools. Students of this class were involved in the study because they are considered to have been exposed to the language for two years since they joined a secondary school level. It is assumed therefore, that a period of two years is enough for such students to get some exposure to the language. This exposure would have pushed them to a higher stage of inter-language journey, something that would make them fit for the study. Form four and form two students were thought unfit for the study since the two classes do have national examinations hence are always busy with preparations. Moreover, form one students were excluded from the study due to the fact that their one year experience of using the language in this level would be not yet enough for the study. A total of fifty four (54) students were involved in this study, six (three boys and three girls) from each school.

Apart from secondary school (form III) students, the study involved twenty TTC diploma trainees. These are students who are trained to be future teachers in secondary schools after a two years course of study in these colleges. Mpwapwa TTC and Capital TTC are two colleges from Dodoma region from which diploma trainees were sampled ten from each college. These were in a second year of study taking English methodology as one of their subject. Moreover, these TTC trainees had gone for their teaching practice for some weeks.

Nine secondary school teachers of English language (one from each secondary school) were involved in this study all being professional trained teachers and most of them with an experience of more than five years at work. The following is a summarised table for the study sample.

TABLE 1:

A SUMMARIZED TABLE FOR THE STUDY's SAMPLE

\begin{tabular}{|l|l|l|l|l|}
\hline Participants & Level & Males & Females & Total \\
\hline Students & Secondary -Form III & 27 & 27 & 54 \\
\hline Teachers & Diploma \& Degree & 5 & 4 & 9 \\
\hline TTC Trainees & Diploma to be & 10 & 10 & 20 \\
\hline Total & & $\mathbf{4 2}$ & $\mathbf{4 1}$ & $\mathbf{8 3}$ \\
\hline
\end{tabular}

Three techniques were used in examining the extent to which English language teachers paid attention to morphosyntactic errors which were committed by students. Documentation was designed to gather information associated teachers CF techniques to correct errors committed by students in their written assignments while observation was employed to collect data connected to teachers CF techniques for students' spoken errors. Moreover questionnaire technique was used to inquire information that confirms from teachers, students and teacher trainees what has been observed in the classroom sessions and what has been documented from students' exercise books. 
Through documentation the researchers cross checked English exercise books from students being guided by the following variables:

(a) To examine whether students used to make correction in each errors committed specifically morpho-syntactic written errors

(b) To examine whether teachers used to insist their students to make correction

(c) To examine whether teachers used to mark students' daily activities

(d) To examine the correction techniques that teachers used when correcting their students' works.

Through classroom observation the researchers observed the teaching procedure and the CF techniques used by teachers to handle all committed morpho-syntactic oral errors also guided by the following variables.

(a) Teachers' attitudes and reaction towards these errors

(b) Corrective feedback techniques used by teachers to correct students' errors

(c) To examine whether teachers correct all errors in the session

(d) To examine whether teachers treat an error committed by a learner as individual problem or the class problem.

All teachers CF techniques both from students' written assignments and spoken errors were collected and were categorized and analysed depending on their similarities.

\section{HANDLING OF LEARNERS’ ERRORS IN ELCS}

The way L2/FL learners' errors are handled can have either constructive or detrimental effect to the learning of the TGL. It is obvious that good treatment of learners' errors heals students' deficiencies while poor treatment makes the condition worse. This section presents the findings on corrective feedback techniques used by teachers in handling students' errors in Tanzania. The presentation is divided into two parts namely; handling of written errors and handling of oral errors.

\section{A. Handling of Written Errors}

Studies have reported that some sorts of meaningful explanation of learners' errors conducted in a non threatening environment lead to improvement of language development (Makino, 1993; and Samar \& Shayestefar, 2009). Moreover, studies have reported that language learners feel the need to be corrected when they commit errors (Makino, 1993). This argument is supported by the findings of the present study whose data indicate that $38(70.4 \%)$ out of 54 (100\%) students in the sample showed that they like their errors to be corrected.

Though students' feelings and previous studies show the need for CF to learners' errors, the findings for the present study reveal that teachers do not mark all the assignments that they provide to their students. Using a documentation technique of data collection, researchers witnessed that English language teachers of some schools had not marked students' works for almost two months. Moreover, in the other schools in the sample, it was found that teachers were not committed to marking of students' works. Therefore, it was common to find that some assignments were marked and others not. Consequently, out of 486 written errors collected in the field, it was only 208 errors equal to $42.8 \%$ which were collected from the marked assignments. This implies that more than half of the written errors (57.2\%) were collected from unmarked assignments as depicted below.

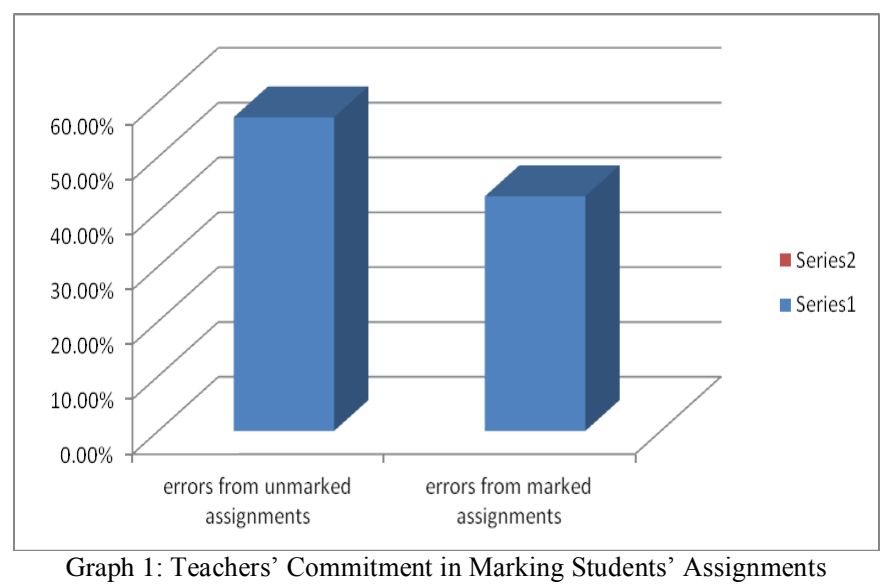

The statistics above implies that a good number of learners' errors in ELCs are not noticed at all and for that matter no repair is done for them. The disadvantage of this is that students do not notice the gap between what they produce and what they are required to produce. That being the case, students are likely to commit the same errors in other assignments including examinations. Moreover, failure to notice learners' errors inhibit teachers from understanding of the common errors that face their students and consequently, teachers fail to provide meaningful assistance to their students since they know nothing or little about learners' errors. 
A number of reasons can be provided by teachers as to why they do not mark all the assignments they provide to their students. However, the data collected in the field show that teachers' ignorance can be the most contributing factor. This claim bases on teachers' responses to a question (from questionnaire) which required them to mention the significance of learners' errors to the teacher. Out of nine SS teachers involved in this study, only four teachers equal to $(44.4 \%)$ were able to mention and the rest five teachers $(55.6 \%)$ were not aware of any significance. Three teachers out of those five provided no answer to this question while two teachers admitted to know nothing.

\section{Common CF Techniques in ELCs in Tanzania}

In his article 'a typology of written corrective feedback types', Ellis (2009) provides six categories of CF techniques which are used by teachers in written assignments. In this typology, the six identified techniques include; direct $\mathrm{CF}$, indirect $\mathrm{CF}$, metalinguistic $\mathrm{CF}$, focused/unfocused $\mathrm{CF}$, electronic $\mathrm{CF}$ and reformulation $\mathrm{CF}$. On the other hand, several studies have attempted to compare the effectiveness of these types of CF so as to suggest the most suitable one. Sheen (2007) identifies some of these studies as Lalande (1982), Robb et al. (1986) and Fazio (2001). However, the absolute superiority of one CF technique over the other is still a contentious issue and for that matter, teachers should be wise enough to select the technique that is capable to facilitate a learning process. To achieve this task, teachers are required to consider factors like students' motivation, attitude, anxiety level, willingness to take risk, age, and pre-requisite knowledge.

The data for the present study show that a total of four CF techniques are commonly used in Tanzanian ELCs. These techniques include focused $\mathrm{CF}$, direct $\mathrm{CF}$, indirect $\mathrm{CF}$ and metalinguistic $\mathrm{CF}$. In all cases, focused $\mathrm{CF}$ technique is not used in isolation of other types mentioned. Using focused corrective technique, teachers tend to select specific error types for correction. Normally, the objective of the lesson guides teachers to specific CF. It was discovered in this study that focused CF dominated unfocused CF in ELCs because each sub-topic in the syllabus is intended to achieve a certain pattern/structure. Therefore, whenever teaching, a teacher has a pattern/structure he needs to achieve and it is this pattern/structure which he focuses to when marking.

Focused CF as it is used in Tanzanian ELCs is not a bad technique of providing feedback to students. Different predictions have been made with respect to the relative effectiveness of focused and unfocused CF. Ellis et al. (2008) cited in Beuningen (2010) for example, claimed that there are theoretical reasons for expecting the focused approach to be more beneficial to accuracy development than unfocused CF. They stated that learners are more likely to notice and understand corrections when they target a specific error type(s). The idea that noticing and understanding are essential for acquisition by Schmidt (1990) led Ellis et al. (2008) to conclude that focused CF has greater potential to impact accuracy development. Furthermore, Sheen (2007) and Bitchener (2008) cited in Beuningen (2010) argued that unfocused CF may not be the most effective correction method because L2 learners have a limited processing capacity. They claimed that asking learners to deal with CF which targets a broad range of linguistic features at the same time might produce a cognitive overload, and prohibit feedback processing.

Focused CF was not used in isolation but the technique was paired with other three CF types as identified above. A direct CF was carried through ways like; crossing the erroneous form and write the correct one near the crossed form, and inserting of the omitted words/ morphemes. Indirect CF was carried through strategies like; crossing the erroneous forms without giving the alternative, circling of the erroneous forms, underlining of the erroneous forms, and the use of the cursor to show omission but without giving the correct form. Lastly, metalinguistic CF was carried through providing some comments (e.g. ww = wrong word; art =article) to learners' errors. Table 2 below shows the distribution of these three CF techniques in ELCs.

TABLE 2:

DISTRIBUTION OF CORRECTIVE FEEDBACK TECHNIQUES IN ELCS

\begin{tabular}{|l|l|l|}
\hline Type of corrective feedback & Frequency & Percentage \\
\hline Indirect & 130 & 62 \\
Direct & 50 & $24 \%$ \\
Metalinguistics & 28 & $13.5 \%$ \\
\hline TOTAL & $\mathbf{2 0 8}$ & $\mathbf{1 0 0 \%}$ \\
\hline
\end{tabular}

The statistics above show that, out of 208 written errors which were collected from the marked assignments, $62.5 \%$ had been marked using indirect CF. This suggests that these $130(62.5 \%)$ errors were marked without indicating the correct form but rather by using some cues to show that there is an error in students' works. On the other hand $24 \%$ were marked using a direct $\mathrm{CF}$ and $13.5 \%$ metalinguistic $\mathrm{CF}$. It is important to note that both indirect $\mathrm{CF}$ and metalinguistic $\mathrm{CF}$ provide no correct form to students instead, the two $\mathrm{CF}$ techniques provide cues to show that something is wrong and students are required to make self repair. Therefore, out of the three techniques in the table, it is only direct $\mathrm{CF}$ which supplies a correct form for erroneous structure.

It is interesting that teachers in Tanzanian ELCs prefer indirect corrective feedback to other types. This implies that students are given an opportunity to make reflection on their errors. This type CF is mentioned in some literatures as the best way of pushing students into both self meditation and repair, thus strengthening their comprehension on the matter.

Beuningen (2010) supports this conclusion when she asserts that, the superiority of indirect approach lies on the fact that it requires learners to engage in a self problem solving, as a result they promote a long-term acquisition. Moreover, Ferris (2002) cited in Sheen (2007) insists that indirect CF is more beneficial than direct correction because it pushes 
learners to engage in hypothesis testing, thereby inducing deeper internal processing which helps them to internalise the correct forms.

Although teachers use CF techniques which allow students to make reflection on their errors and eventually self correction, it is discouraging to find that teachers do not make follow up to see whether students work upon the $\mathrm{CF}$ provided. In a documentation exercise, it was discovered that most students rarely do corrections for the previously committed errors. These students are free to write new assignments and submit it to their teachers who in turn mark the assignments without asking about the corrections for the previous errors. Moreover, it is discovered that even those corrections written by students are rarely marked. This observation was confirmed through students' responses to two questions below as they appeared in their questionnaire.

TABLE 3:

THE STATUS OF ERROR CORRECTION IN ELCS

\begin{tabular}{|c|c|c|c|c|c|c|c|c|}
\hline \multirow[t]{3}{*}{ Questions } & \multicolumn{8}{|c|}{ Answers } \\
\hline & \multicolumn{2}{|c|}{ Yes } & \multicolumn{2}{|c|}{ No } & \multicolumn{2}{|c|}{ Sometimes } & \multicolumn{2}{|c|}{ Total } \\
\hline & $F$ & $\%$ & $f$ & $\%$ & $f$ & $\%$ & $f$ & $\%$ \\
\hline $\begin{array}{l}\text { Do you make corrections } \\
\text { after teachers' feedback? }\end{array}$ & 12 & 22.2 & 6 & 11.1 & 36 & 66.7 & 54 & 100 \\
\hline $\begin{array}{l}\text { Does your teacher mark } \\
\text { the corrections? }\end{array}$ & 6 & 11.1 & 4 & 7.4 & 44 & 81.5 & 54 & 100 \\
\hline
\end{tabular}

The findings in this table imply that teachers' emphasis on error correction is very low. This teachers' behaviour (of not emphasising) has some disadvantages in the learning of their students. One of these disadvantages is that, nothing will push students to make reflection on their errors and that being the case; students fail to notice the gap between what they produce and what they are required to produce. Generally, indirect CF requires teachers' follow up so as to make sure that students correct their errors immediately after the corrective feedback has been provided by the teacher. This is to say, although teachers in ELCs seem to prefer indirect CF to others, they lower the effectiveness of this technique through their failure to comply with the requirement of the technique.

\section{B. Handling of Oral Errors}

As discussed above, the information on handling spoken errors was gathered through researchers having an opportunity to witness the way teaching and learning process is carried in ELCs. Throughout observation, the researchers kept on noting the committed oral errors as well as teachers' reaction towards those errors. Below are observational results of teachers' treatment of oral errors and they are presented in table 4 basing on the taxonomy for corrective feedback techniques by Lyster and Ranta (1997).

TABLE 4:

DISTRIBUTION OF ORAL CF TECHNIQUES IN ELCS

\begin{tabular}{|l|l|l|}
\hline Types of CF & Frequency & Percentage \\
\hline explicit & 38 & $35.8 \%$ \\
recast & 28 & $26.4 \%$ \\
clarification request & 17 & $16.0 \%$ \\
metalinguistic feedback & 11 & $10.4 \%$ \\
elicitation & 03 & $2.8 \%$ \\
repetition & 03 & $2.8 \%$ \\
not reacted upon & 06 & $5.7 \%$ \\
\hline Total & $\mathbf{1 0 6}$ & $\mathbf{9 9 . 9 \%} \approx \mathbf{1 0 0}$ \\
\hline
\end{tabular}

As shown in table 4 above, explicit CF $(35.8 \%)$ is the most applied technique in handling oral errors in ELCs. Explicit CF is followed by recast CF which makes (26.4\%) of teachers' feedback turns towards learners' oral errors in ELCs. The two techniques comprise more than half of the CF applied by teachers in ELCs. However, neither explicit nor recast provides opportunities to students to reformulate their utterances whenever they commit errors since the reformulation of erroneous sentences is provided by teachers. Therefore these two types of CF do not expose students to a reflection of their erroneous utterances but rather students blindly repeat the teacher's reformulated utterances (Beleghizadeh \& Abdi, 2010).

Apart from explicit and recast, the uses of other CF techniques are too limited in spite of their usefulness in language teaching. Clarification request, elicitation and repetition are good techniques in terms of giving learners opportunities for making reflection and reformulate their prior erroneous utterances. Despite this strength, their application in ELCs is either disvalued or ignored. Below, graph 2 provides a pictorial representation of the application of various $\mathrm{CF}$ techniques in English language classrooms (ELCs). 


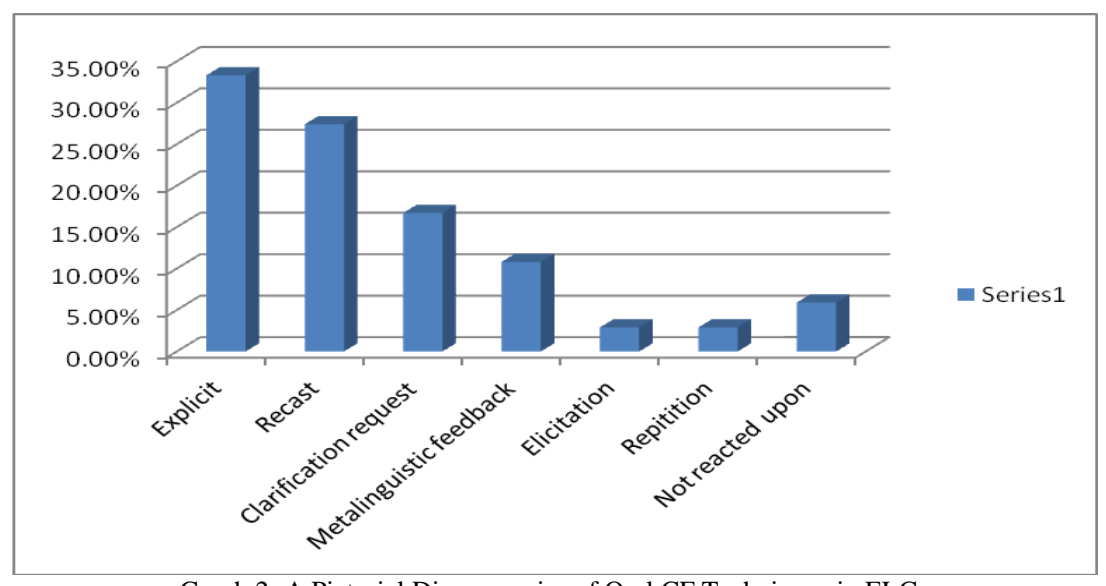

Graph 2: A Pictorial Discrepancies of Oral CF Techniques in ELCs

The observation findings in table 4 above are supported by teachers' responses to a question in appendix V. The question required them to explain their preferences for the techniques which they always use to handle learners' oral errors. The answers in table 5 below were provided for the question.

TABLE 5:

SECONDARY SCHOOL TEACHERS' PREFERENCE FOR ORAL CF TECHNIQUES

\begin{tabular}{|l|l|l|l|}
\hline Answers & Type of CF & $\boldsymbol{f}$ & $\mathbf{\%}$ \\
\hline $\begin{array}{l}\text { - I always reform the sentence and ask them to } \\
\text { repeat after me }\end{array}$ & Explicit & 3 & 33.3 \\
- I always ask them to repeat the sentence & Clarification & 1 & 11.1 \\
- I reformulate the sentence by myself (they did & Recast & 3 & 33.3 \\
not say if they allow students to repeat the & & & \\
$\begin{array}{l}\text { utterance after them) } \\
\text { - No answer }\end{array}$ & - & 2 & 22.2 \\
\hline Total & - & $\mathbf{9}$ & $\mathbf{9 9 . 9} \approx \mathbf{1 0 0}$ \\
\hline
\end{tabular}

Note: $f=$ frequency

From table 5 above, teachers' answers justify that both explicit and recast are mostly preferred to other techniques. Basing on these answers, the two techniques together make a total of $66.6 \%$ of all techniques for handling oral errors. This figure shows significantly how the uses of other techniques in ELCs are limited. On the other hand explicit technique emerged as the leading and the most preferred by TTC's trainees (diploma in education students). Answering the question which required them to explain the way they handled oral errors in their teaching practice, $35 \%$ of them showed their preference to explicit technique. Table 6 below shows TTC trainees' preference for corrective feedback techniques for oral errors.

TABLE 6:

TTC TRAINEES’ PREFERENCE FOR ORAL CF TECHNIQUES

\begin{tabular}{|c|c|c|c|}
\hline Answers & Type of CF & $f$ & $\%$ \\
\hline $\begin{array}{l}\text { - I used to reform the sentences and ask them to repeat after me } \\
\text { - I corrected them by uttering the correct form } \\
\text { - I asked them to repeat the sentence } \\
\text { - I used to guide them to identify their errors (but did not say how?) } \\
\text { - I identified the error and ask them to correct } \\
\text { - I do not remember } \\
\text { - No answer }\end{array}$ & $\begin{array}{l}\text { Explicit } \\
\text { Recast } \\
\text { Clarification } \\
\text { Metalinguistic } \\
- \\
-\end{array}$ & $\begin{array}{l}7 \\
3 \\
2 \\
1 \\
2 \\
3 \\
2\end{array}$ & $\begin{array}{l}35 \\
15 \\
10 \\
5 \\
10 \\
15 \\
10\end{array}$ \\
\hline Total & - & 20 & 100 \\
\hline
\end{tabular}

From the presentation above, it is unfortunate that teachers in ELCs prefer CF techniques which hardly enable students to notice errors in the utterance they make. Consider the following interaction between a teacher versus his students in B1secondary school.

Teacher: Who else can make the sentence using this structure?

Teacher: Maria, stand up!

Student: Despite Juma is intelligent he failed his examination

Teacher: (providing a recast feedback) Despite Juma's intelligence he failed his examination. Another sentence....... Aisha (he allowed Aisha to stand up and make another sentence).

The teacher in the above example provided a recast CF to a student's sentence in order to repair the student's erroneous sentence which had some errors in the underlined part. However, the way a teacher presented the corrected version was as if he was just repeating the student's utterance. Indeed, it required someone who had enough knowledge on the structure to recognise that a teacher made a modification to a student's sentence. Such kinds of CF are worthy for 
nothing in the sense that, the goal of CF is to let students improve their weaknesses but here teachers use CF which do not achieve the intended goal. Nicholous et al. (2001) report the same observation when he asserts that 'in their study Lyster and Ranta (1997) found that teachers often continued with their turn after recasting the students' utterance without waiting for students' response to the feedback'.

Although CF techniques like clarification request, metalinguistic feedback elicitation and repetition seem to be ignored in ELCs, findings form previously conducted research indicate that such CF techniques are the best in facilitating students' uptake and noticing of the knowledge gap. This conclusion is true since the role of teachers in these types of CF is not to give out the correct versions of students' erroneous utterances, but rather to facilitate students to recognise and correct their faults by themselves.

Carroll and Swain (1993) investigated the effects of different feedback techniques on L2 learners' ability and found that the group that received metalinguistic explanation were able to attain a long-term memory (Baleghizadeh et.al, 2010). Again, both Nicholous et al. (2001) and Samar \& Shayestefar (2009) report that Lyster and Ranta (1997) classified the students' uptake in respect of the teachers' feedback and they found that recast resulted in less uptake than other types, while elicitation and clarification were more promoting. In a similar vein, Lochtman (2002) cited in Samar \& Shayestefar (2009) points out a higher frequency of No-uptake after recasts but finds metalinguistic and elicitation feedback useful in leading to successful uptake. Another evidence comes from Rahimi and Dastjerdi (2012) who report on one experimental research which investigated the effect of recast and metalinguistic $\mathrm{CF}$ on the acquisition of the past tense -ed form in a normal classroom situation to ESL learners. The overall results showed that metalinguistic CF group performed better than recast CF group.

The discussion above has shown teachers' preference to some CF over others. However, it is astonishing to find that most teachers do not use pedagogical criteria to select the type of CF they are using in their teaching. This was revealed by both secondary school English language teachers and T.T.C trainees when they were answering a question which required them to explain why they handle students' oral errors the way they do. Table 7 below presents their answers.

TABLE 7:

REASONS BEHIND THE SELECTION OF ORAL CF

\begin{tabular}{|l|l|c|c|}
\hline Respondents & \multicolumn{1}{|c|}{ Reasons for selection of a CF } & $f$ & $\%$ \\
\hline SS Teachers & This is the way many teachers do & 3 & 33.3 \\
& It is a simple way of providing feedback & 1 & 11.1 \\
& This CF does not require much time & 2 & 11.1 \\
& This is the way I know & 1 & 22.2 \\
& This type of CF promotes students' uptake & 1 & 11.1 \\
& It is enjoyed by students & 9 & 11.1 \\
\hline \multicolumn{1}{|c|}{ TOTAL } & $f$ & $99.9 \approx 100$ & $\%$ \\
\hline Respondents & & 4 & 5 \\
\hline TTC trainees & This CF is simple to handle & 2 & 20 \\
& It consumes no time & 5 & 25 \\
& It promotes students' understanding & 1 & 10 \\
& It is common among many teachers & 2 & 25 \\
& It is the technique I know & 1 & 5 \\
& That is how I was taught & 20 & 10 \\
& This technique is easier than others & 5 & 100 \\
\hline
\end{tabular}

Table 7 shows that, it is one SS teacher who answered that 'this type of CF promotes students' uptake'. This finding implies that, there are only few teachers who provide CF basing on the academic benefit of the technique to their students. It is only this single reason equal to $11.1 \%$ that seems to conform to pedagogical principles. In contrast, the rest of the reasons which were provided by teachers (almost 88.9\%) seem to base on; experience (e.g. this is the way many teachers do), teachers' need to simplify their task (e.g. this is simple to handle; the technique does not consume time), and ignorance (e.g. this is the way I know). The same situation happened to TTC trainees whereby out of 20 participants, only two of them (equal to 10\%) provided the answer which conform to pedagogical principles. These two TTC trainees were of the view that, the reason behind the selection of CF techniques during their teaching practice was the belief that the techniques were good for promoting students' understanding. In contrast to these two, the rest 18 equal to $90 \%$ seem to have selected $\mathrm{CF}$ in their teaching practice basing on experience; need to simplify the work and ignorance.

\section{CONCLUSION}

This paper has attempted to assess the techniques that are used by English language teachers in handling students' morpho-syntactic errors in Tanzania particularly Dodoma region. Through observation in the classroom during teaching session, documenting how teachers handled errors in students written assignments and through letting teachers respond to some questions four important things are discovered as far as teachers' CF techniques are concerned, there are four important findings to note. The first one is that teachers are not committed in marking students' assignments and for that matter many students' assignments are not marked. This situation affects both students and teachers in the way that, students fail to understand whether what they write is right or not and for that matter there is a danger to understand 
things in a wrong way. Teachers are affected in the way that, they fail to notice and understand the common language problems that face their students and for that matter, they cannot assist their students effectively. The second finding is that, most of the CF techniques which are used by teachers in ELCs are not pedagogically effective to treat students' errors. The third finding; many teachers select the CF to use in classrooms basing on either experience or the need to simplify their work and not the pedagogical requirements. The last finding is that teachers are blamed for not insisting their students to work upon their teachers' corrective feedback. This teachers' relaxation, has cultivated in students the behaviour of not writing corrections for the errors.

\section{REFERENCES}

[1] Ashwell, T. (2000). Patterns of teacher response to student writing in a multiple -draft Composition classroom: Is content feedback followed by form feedback the Best method? Journal of second language writing 9, 227-258.

[2] Baleghizadeh, S. \& H. Abdi (2010). Recast and Its Impact on Second Language Acquisition. International Journal of Language Studies 4, 51-68.

[3] Beuningen, C. V. (2010). Corrective Feedback in L2 Writing: Theoretical Perspectives, Empirical insights, and Future Directions. International Journal of English Studies 10, 1-27.

[4] Biseko, J. M. (2012). Nature and Treatment of Secondary School Students' Morph-syntactic errors in Tanzanian English Language Classrooms. Unpublished dissertation -University of Dodoma.

[5] Bitchner, J. (2008). Evidence in support of written corrective feedback. Journal of Second Language Writing 17, $102-118$.

[6] Brown, H. D. (1994). Principles of Language Learning and Teaching ( $3^{\text {rd }}$ ed). New Jersey: Prentice Hall.

[7] Carroll, S. \& M. Swain. (1993). Explicit and implicit negative feedback: An empirical study of the learning of linguistic generalizations. Studies in Second Language Acquisition 15, 357-366.

[8] Chandler, J. (2003). The efficacy of various kinds of error feedback for improvement in the accuracy and fluency of L2 student writing. Journal of Second Language Writing 12, 267-296.

[9] Corder. S. P. (1967). The Significance of Learners' errors. International Review of Applied Linguistics 5, 161-169.

[10] Darus, S. \& K. Subramaniam. (2009). Error Analysis of the Written English Essay of Secondary School Students in Malaysia. European Journal of Social Sciences 8, 483-495.

[11] Economic Commission for Africa. (2003). Poverty Mapping for Selected African Countries, Accessed on 23 ${ }^{\text {rd }}$ may 2012, from http://www.uneca.org/publications/ESPD/Povertyplofiles.Pdf.

[12] Ellis, R. (2009). A Typology of Written Corrective Feedback Types. ELT Journal 63, 97- 107.

[13] Fathman, A., and E. Whalley. (1990). Teacher response to student writing: Focus on form versus content. In B. Kroll (Ed.), Second language writing: Research insights for the classroom Cambridge: Cambridge University Press. 178-190.

[14] Fazio, L. (2001). The effect of corrections and commentaries on the journal writing accuracy of minority and majority language students. Journal of Second Language Writing 10, 235-249.

[15] Ferris, D.R. (1997). The influence of teacher commentary on student revision. TESOL Quarterly 31, 315-339.

[16] Ferris, D. R. (2002). Treatment of error in second language writing class. Ann Arbor: University of Michigan Press.

[17] Ferris. D. R. \& B. Roberts. (2001). Error feedback in the L2 writing classes: How explicit does it need to be? Journal of second language writing 10, 161-184.

[18] Herrera, S. (2011). Exploring the Role of Corrective Feedback in Second Language Writing, Unpublished MA Dissertation, University of British Columbia.

[19] Hyland, K. (2003). Second language writing. Cambridge, UK: Cambridge University Press.

[20] Kepner, C.G. (1991). An experiment in the relationship of types of written feedback to the development of second language writing skills. Modern language Journal 75, 305-313

[21] Keshavarz, M. H. (1999). Contrastive analysis and Error Analysis ( $3^{\text {rd }}$ ed), Tehran: Rahnama Publications.

[22] Lalande, J.F. (1982). Reducing Composition errors: An experiment. Modern Language Journal 66, 140-149

[23] Liu, Y. (2008).The Effects of Error Feedback in Second Language Writing. Arizona Working papers in SLA \& Teaching 15, 65- 79.

[24] Lyster, R. \& L. Ranta. (1997). Corrective feedback and learner uptake: Negotiation of form in communicative classrooms. Studies in Second Language Acquisition 19, 37-66.

[25] Makino, Y. Y. (1993). Learner Self-correction in EFL Written Compositions. ELT Journal 47, 337-341.

[26] Nayernia, A. (2011). Writing Error, What They can Tell a Teacher?. The Modern Journal of Applied Linguistics 3, $200-217$.

[27] Nicholas, H., P. M. Lightbown \& N. Spada. (2001). Recasts as Feedback to Language Learners. Language Learning 51, 719758.

[28] Nzama, M. V. (2010). Error Analysis: A study of Errors Committed by Isizulu Speaking Learners of English in Selected Schools, Unpublished MA Dissertation, University of Zululand.

[29] Polio, C., C. Fleck \& N. Leder. (1998). "If I only had more time:" ESL learners' changes in linguistic accuracy on essay revisions. Journal of Second Language Writing 7, 43-68.

[30] Rahimi, A. \& H.V. Dastjerdi. (2012). Impact of Immediate and Delayed Error Correction on EFL Learners' Oral Production: CAF. Mediterranean Journal of Social Sciences 3, 45-54.

[31] Robb, T., S. Ross \& I. Shortreed. (1986). Salience of feedback on error and its effect on EFL writing quality. TESOL Quarterly 20, 83-93.

[32] Rubagumya, C. (2010). Teaching and Learning English in Africa: Do Learners Matter? Keynote Address Delivered at the SUZA- SPINE International Symposium: Teaching, Learning and Assessing in Second Language Contexts, 1-19, $2^{\text {nd }}-3^{\text {rd }}$ December.

[33] Samar, G. R. \& P. Shayestefar. (2009). Corrective Feedback in EFL classrooms: Learner Negotiation Strategies and Uptake. Journal of English Language Teaching and Learning 212, 107-134. 
[34] Semke, H. (1984). The effects of the red pen. Foreign Language Annals 17, 195-202.

[35] Schmidt, R. (1990). The role of conscious in second language learning. Applied Linguistics 11, 17-46.

[36] Sheen, Y. (2007). The Effects of Focused Written Corrective Feedback and Language Aptitude on ESL's Acquisition of articles. TESOL Quarterly 2, 255-83.

[37] Sheppard, K. (1992). Two feedback types: Do they make a difference? RELC Journal 23, 103-110.

Rafiki Yohana Sebonde is a lecturer in the department of foreign language and literature at the University of Dodoma. Her areas of academic interest include Sociolinguistics, Second Language Teaching, African languages particularly Kiswahili, and language contact and bilingualism. Currently she teaches General Research Methodology in Humanities, Introduction to Sociolinguistics, History and Structure of Kiswahili and Language in the Media.

John Misana Biseko is an assistant lecturer in the department of foreign languages and literature at the University of Dodoma Tanzania. Before joining the University of Dodoma as an academic staff, he taught English language at different primary and secondary schools in Tanzania. His areas of interest are second Language Teaching, Syntax and Historical Linguistics. Currently, he teaches Modern Linguistics Theories. 